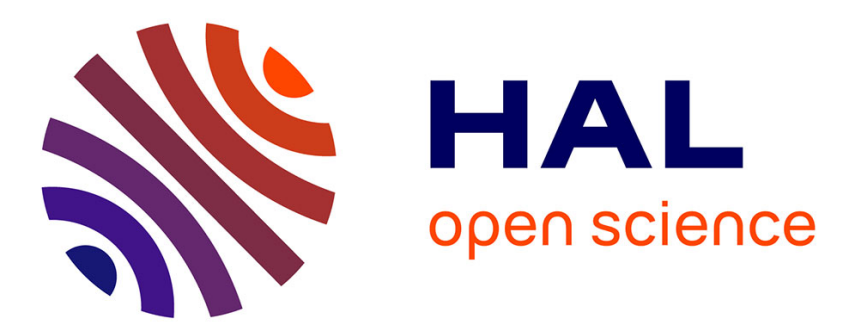

\title{
MNEs and policy networks: Institutional embeddedness and strategic choice
}

Yorgos Rizopoulos, Dimitrios E Sergakis

\section{To cite this version:}

Yorgos Rizopoulos, Dimitrios E Sergakis. MNEs and policy networks: Institutional embeddedness and strategic choice. Journal of World Business, 2010, 45 (3), pp.250-256. 10.1016/j.jwb.2009.09.002 . halshs-01968233

\section{HAL Id: halshs-01968233 \\ https://shs.hal.science/halshs-01968233}

Submitted on 14 Jan 2019

HAL is a multi-disciplinary open access archive for the deposit and dissemination of scientific research documents, whether they are published or not. The documents may come from teaching and research institutions in France or abroad, or from public or private research centers.
L'archive ouverte pluridisciplinaire HAL, est destinée au dépôt et à la diffusion de documents scientifiques de niveau recherche, publiés ou non, émanant des établissements d'enseignement et de recherche français ou étrangers, des laboratoires publics ou privés. 
Journal of World Business, vol. 45 (3), 2010: 250-256

(doi:10.1016/j.jwb.2009.09.002)

\title{
MNEs and policy networks: Institutional embeddedness and strategic choice
}

\author{
Yorgos A. Rizopoulos* and Dimitrios E. Sergakis ${ }^{* *}$
}

\begin{abstract}
Political strategies are a crucial matter for MNEs in the context of globalization. We argue that MNEs' influence on political decision-making depends on their insertion into policy networks, which define the interaction patterns of business/government relations in different issue-areas. Then, we propose a stylized taxonomy regarding the differentiation of MNEs' political leverage in various domains, at a home country level. Finally, we explore the influence of political power at home on MNEs' strategic approaches to the host countries, taking into account the bargaining power of local actors in the concerned issue-areas. This framework adds on the understanding of how MNEs influence political decisions and how their strategies regarding host countries are influenced by political forces in their home country.
\end{abstract}

Keywords: Business-government relations; MNEs Political Strategies; Policy Networks.

A firm's political strategy aims to modify its set of opportunities or that of its competitors (Baysinger, 1984) by creating political advantages (Yoffie, 1988). It therefore concerns all the activities engaged with the intention of influencing and orienting state/government ${ }^{1}$ action (Epstein, 1969). As

\footnotetext{
* Professor of Economics, CRIISEA, University of Picardie, 10, Placette Lafleur, BP 2716, 80027 Amiens Cedex 1, France, tel + 333228268 03, fax + 333228271 27. E-mail : yorgos.rizopoulos@u-picardie.fr.

${ }_{* *}$ PhD candidate University of Paris-1 Panthéon Sorbonne, 106-112 Bd de l'Hôpital, 75647 Paris, Cedex 13, France and Lecturer, CRIISEA, University of Picardie, 10, Placette Lafleur, BP 2716, 80027 Amiens Cedex 1, France, tel + 333228268 03, fax + 333228271 27. Email :dimsergakis@gmail.com.

${ }^{1}$ In this respect, we follow Murtha \& Lenway (1994) who distinguish between the government as a decision-making group and the state as an organizational structure embodying national governance capabilities. Firms interact not only with politicians and members of the government but also with administrative structures and public agencies (Hillman \& Keim, 1995) that have institutional functions (creating and applying rules) and that frequently play an active role in the economic game (commissions in charge of competition, regulation, standards, etc.).
} 
underlined by Anastassopoulos et al. (1985) and Baron (1995), political strategies reinforce and complement competitive strategies.

Different categories of political strategies are identified in the literature (for an overview, see Hillman et al., 2004). Keim \& Zeihaml (1986) put the constituency building, political action committee contributions, advocacy advertising, coalition building and lobbying forward, while Hillman \& Hitt (1999) distinguish three types of generic political strategies: information, financial incentives and constituency building. Concerning more specifically the political activities of multinational enterprises (MNEs), the existing literature offers some crucial insights. Boddewyn \& Brewer (1994) bring out different levels of intensity and forms of political behavior - compliance, avoidance, circumvention, conflicting and partnership bargaining - following the proactive approach developed by Boddewyn (1988). Other scholars investigate the relationship between market conditions and firm characteristics as predictors of firms' political activities designed to manage the international non-market environment (Keillor \& Hult, 2004).

This paper explores the links between MNEs' political strategies and institutional environments. In the same perspective, the political bargaining models (Levy \& Prakash, 2003; Eden et al, 2005) point out the density of the repeated MNEs/government relations and the emergence of common interests, while other recent research draws the institutional determinants (Hillman, 2003; Rodriguez et al., 2006) and analyzes MNEs' political activities as 
multilevel strategies shaped by differing non-market institutions (Windsor, 2007).

Our work adds value to the literature by developing how MNEs influence political decisions and how their strategies regarding host countries are influenced by political forces in their home country. We put forward the structural features of the MNEs/government interactions, and complete the issue-areas analytical framework proposed by Brewer (1992) that places an emphasis on the differentiation of MNEs' fields of political intervention.

In this perspective, we refer to the policy networks concept (Wilks \& Wright, 1987, Rhodes \& Marsh, 1990). As an analytical tool of the intermediate levels of government, it gives the possibility to contextualize the framework of MNEs' political strategies by avoiding the pitfalls of the approaches in terms of 'national systems of governance' (corporatism/elitism or pluralism). Indeed, this concept is suitable to reveal the variety of business/government relationships, not only between different countries, but also inside any given country.

We formulate some interrelated theoretical propositions. We argue that the MNE's political influence depends on its possibility to intervene in relevant policy networks. The taxonomy we suggest regarding political leverage in the home country stands on the structural features of those networks and the MNE's position inside them. We also develop the idea that some links do exist between the MNE's potential to influence home policies 
and its strategic approach towards host countries ${ }^{2}$. So, we propose a joint overview of two dimensions usually treated separately, which is MNE/home country and MNE/host country relationships.

As such the paper is organised in eight sections. The first section outlines the policy networks concept as an analytical tool of the MNEs/government interaction patterns. The next section put forward the links with the issue-areas approach. The third section presents the generic types of policy networks. Then, we analyse the impact of the MNE's structural position and, after that, four configurations concerning the MNE's political leverage at home are identified. In the sixth section, the host country's bargaining power is apprehended at the issue-areas level. Next, we explore the strategic choices of MNE's towards host countries. We conclude with the contribution of the paper, some limitations and the future perspectives of our research.

\section{The policy networks as framework of MNEs/government interactions}

Firms' political strategies are implemented in the framework of structured interactions with governments.

The policy networks concept (Rhodes, 1981 et 1986; Wilks \& Wright, 1987; Rhodes \& Marsh, 1990) relates to the interplay of different interest groups in public decision-making and action. It stresses the exchange processes between organizations (Levine \& White, 1961; Pfeffer \& Salancik,

\footnotetext{
${ }^{2}$ Needless to say that many other factors affect these options: the general political-economic context and risks, the structural characteristics of MNEs, the domain of activity, etc. These will not be dealt with in this paper, but we think that such dimensions can easily be integrated in the analytical scheme developed below.
} 
1978) and the complexity of ties binding major stakeholders (firms, bureaucrats and politicians) by resource interdependencies.

Generally, MNEs have considerable weight in terms of employment, technological knowledge and financial power. These assets enable them to influence the political decision-making process and the resulting resource allocation, shape the rules of the game and, whenever possible, make political priorities match their own objectives. In return, politicians and bureaucrats obtain otherwise inaccessible resources determining their policies' effectiveness. In such conditions, government can be found remodelling and dominating MNEs' strategies or, on the contrary, being caught serving the latter's interests. The ties linking them often stand on this reciprocity balance and mutual dependency. Each party's outputs constitute inputs for the other.

According to the policy networks theoretical framework, the business/government interaction patterns, the consultation procedures, the organizational forms they induce, the distribution of power (based on the accumulated resources and action capabilities) and the set of regulating rules are usually stable and permanent. The political decision-making occurs within interorganizational networks of lasting nature (Klijn \& Teisman, 1997), which constitute the institutional environment of MNE/government relationships and imply various degrees of embeddedness ${ }^{3}$ (Granovetter, 1985). In other words,

\footnotetext{
${ }^{3}$ This concept - commonly used to illustrate links between economic activities and social structures - also seems relevant when applied to all non-market, including political, relationships.
} 
MNEs' perceptions and strategic goals are constructed in reference to the policy networks they are involved in.

Proposition 1. Policy networks are systems of interest intermediation inside which MNEs negotiate issues crucial to their activity with state/government actors.

\section{Policy networks and issue-areas}

The implementation of firms' political strategies does not imply a unique model of business/government relationships.

One of the most interesting contributions of the policy networks concept is the idea of an intermediate level of government (subgovernment) which means specific interaction patterns in special areas of public policy (Freeman \& Parris Stevens, 1987; Ripley \& Franklin, 1987). Interest groups, bureaucrats and politicians interact within multiple networks in diverse fields, with varying influence and bargaining potential. The policy-making is fragmented and we can hereby predict a wide range of policy networks inside one single country representing a diversity of stakeholders' relational patterns. For instance, petroleum, steel or pharmaceutical companies are not integrated in the same policy networks. Their relationships with government, their possibilities to influence policy decision-makers, their political strategies, are not similar either.

The convergence with the issue-areas approach becomes quite obvious here. Indeed, Brewer's seminal work $(1992,2005)$ stresses the variety of 
business-government relationships and their outcomes across different domains. Interconnections and mutual influence will depend on each issuearea. Levy \& Prakash (2003) also underline the differences (and conflicts) existing between the state's intervention in different domains. Other recent research work explains why interaction takes place at the issue level and stresses that the attractiveness of political markets depends on various policy issues while a firm's participation in the public policy process is more or less successful according to the saliency of the issue (Bonardi \& Keim, 2005). ${ }^{4}$

What the concept of policy networks adds is the possibility to integrate the institutional characteristics of various issue-areas into the analysis. While issue-areas are mostly defined by their impact (distribution, regulation, redistribution and protection-interaction), policy networks crystallize the institutional features of the game (Katzenstein, 1978) and are defined according to their integration, stability, exclusivity and dominant interests. Focusing on the interaction patterns between firms and state/government agencies, the policy networks approach is complementary to the issue-areas one.

Proposition 2. The institutional features of the policy networks differentiate the business/government interactions and MNEs' political leverage in each issue-area.

\footnotetext{
${ }^{4}$ It is striking that Murtha \& Lenway (1994), who also introduce the concept of policy networks, end up using a classification of nations according to the importance of price mechanisms (transactional governance) and the allocation of property rights between public and private sectors. By doing so, they leave out the variety of public policy domains implied by the policy networks concept.
} 


\section{Open and closed policy networks}

According to the terms used by Bourdieu (1985), Coleman (1988) and public administration scholars (Schaap \& Van Twist, 1997), we can distinguish two polar types of policy networks, the open and closed ones. These terms describe the relative isolation of the network from external influences, the positions and the plurality of the participating actors, the nature of the ties linking them together and the presence or not of dominant interest groups. The open or closed character of a policy network depends on some structural variables such as centralization, density, multiplexity, strength of ties, dominance, connexity and homogeneity. ${ }^{5}$

Table 1. Features of closed and open policy networks

Type of network

Structural

variables

\begin{tabular}{|l|l|l|}
\cline { 2 - 3 } \multicolumn{1}{c|}{} & Closed & Open \\
\hline Centralization & High & Low \\
\hline Density/Cohesion & High & Low \\
\hline Strength of ties & Strong & Weak \\
\hline Dominance & Yes & No \\
\hline $\begin{array}{l}\text { Connexity/ } \\
\text { Homogeneity/ } \\
\text { Convergence }\end{array}$ & $\begin{array}{l}\text { High (but the } \\
\text { impact also } \\
\text { depends on the } \\
\text { existence of } \\
\text { cliques) }\end{array}$ & Low \\
\hline
\end{tabular}

\footnotetext{
${ }^{5}$ In the political science literature, closed policy networks correspond to the so called policy communities (Rhodes 1986), while open policy networks correspond to the thematic networks. We privilege the "open" and "closed" terms in order to make a link with the tools of the social networks and graphs theory (Ouimet \& Lemieux, 2000) enabling a more rigorous definition of the various types of policy networks.
} 
Inside a closed policy network, strong ties - given their transitive character - imply recurrent and dense relationships (overlapping and "multiplex" links) of a small number of public and private actors. Integrated members are isolated from external influences and have shared interests, values, preferences and, even, ideology. This type of network, characterized by high centralization, cohesion, convergence and exclusivity, constitutes an institutional environment suitable to build-up a dominant position inside a specific issue-area. ${ }^{6}$

The development pattern of the Russian oil industry is an example of interweaved closed policy networks, structured around some major industrial and financial groups linked by complex relationships of exclusivity with the Federal State and the regional authorities. ${ }^{7}$ The foreign companies are compelled to operate either by creating a joint venture or by entering the capital of a Russian company, while it is unlikely that the authorities will favor a significant control of the national oil companies by foreign partners. ${ }^{8}$

On the contrary, open policy networks are characterized by ties among a high number of participants with well-balanced bargaining power and little

\footnotetext{
${ }^{6}$ According to Bourdier (1985), the effectiveness of exchanges between the participants of closed networks is reinforced by the consciousness of belonging to the same community. Coleman (1988) stresses on mutual trust and shared norms of behavior. As Schaap \& Van Twist (1997) have pointed out, the relative closedness of a network has both social (exclusion of other actors) and cognitive (inability or unwillingness to perceive the reality outside the network) dimensions.

7 For instance, Gazprom's internationalization is one of the privileged instruments of the Russian State's geopolitical strategy.

${ }^{8}$ The modification of the Production Sharing Agreements law, in 2003, was an important signal. In this year, when Yukos entered into discussions with Exxon-Mobil for the sale of $40 \%$ of its shares, the State blocked the transaction and a Chinese company was excluded from the privatization of Slavneft in favour of TNK and Sibneft.
} 
interdependence. Because of low centralization, density and cohesion, interconnectivity is lacking and contacts are generally weak and distant. Without dominant or systematically favored interests, actors' interactions are based on consultations and exchanges of information. ${ }^{9}$

Global Compact is an example of an open policy network comprising the UN, MNEs, international labor organizations, NGOs and university-based research centers. Inside this network, MNEs are challenged to move toward good corporate practices, rather than relying on their superior bargaining position vis-à-vis national authorities, especially in small and poor states (Ruggie, 2001). Corporate change is induced by an ongoing collective learning process rather than regulation. The strengths and weaknesses ${ }^{10}$ of Global Compact stem from this adopted model.

An open network procures more information (Granovetter, 1973), but also implies loose links, which weaken the influence of participating actors. Closed networks are poorer in information but their participants are not trapped into "structural holes" (Burt, 1992). They imply mutual influence and systematic support of specific interests, particularly when powerful core actors have an unambiguous hierarchy of preferences and goals (Laumann \& Knoke, 1987). The impact of such networks is further strengthened when exterior - or

\footnotetext{
${ }^{9}$ Pluralist patterns could be common in domains where gains are not dividable, while private interests may benefit from close and exclusive relationships with state agencies in cases where benefits are dividable.

${ }^{10}$ The fact that the network recognizes and promotes a company's "good" practices provides no guarantee that the same company does not engage in "bad" practices elsewhere. Indeed, it may even invite a measure of strategic behaviour (Nestlé's interest in the Global Compact undoubtedly reflects a desire to balance criticism on the breast milk substitute).
} 
peripheral inside the policy domain - actors have a weak perception of their own interests and/or suffer from a lack of coordination.

Proposition 3. Closed policy networks offer to MNEs more possibilities to influence public decision making than open policy networks.

\section{Impact of the MNE'S structural position}

On the whole, the MNE's position will be related to its market (financial, technological, and productive) and non-market assets. The two types of assets are not unrelated although some firms possess important market but weak non-market assets. As a consequence, their political leverage is affected (for instance, the tobacco industry).

The literature on firms' political strategies stresses the importance of some specific non-market assets (Epstein, 1969; Keim and Zeithaml, 1986; Getz, 1993). These assets can be tangible or not (Boddewyn \& Brewer, 1994), such as time slots devoted to political action by company executives, organizational skills, and access to strategic information or to state (government) officials. Yoffie (1988) stresses the managers' expertise, knowhow and skills in dealing with stakeholders, and the social reputation of the firm, built on its attitude concerning social issues. Specific information is also very important as regards the process of political decision-making, the orientation of the political agenda or the legitimization of firms' goals (Vogel, 1996; Lenway \& Rehbein, 1991). Baron (1995) considers these non-market assets to be of strategic value if they are rare, sustained and not easily imitated. 
They are the determining factors of a firms' capacity to influence public policies and promote its own interests.

We consider as a proxy of the firm's non-market assets the nature and number of its links with other actors. In this perspective, the measures of power proposed by Burt (1992) can be applied to the MNE's position inside a policy network:

- $\quad$ Centrality (effective links compared to the number of the possible ones).

- $\quad$ Intermediate centrality (positions in the minimum length paths geodesic distance - linking the other participants).

- $\quad$ Strength of links (number of strong ties with the other participants).

- Exclusivity of links (degree of the other participants' exclusive relationships).

- $\quad$ Power of the linked actors.

- $\quad$ Structural holes (non redundant relationships between the other network's participants).

Proposition 4. The MNE's structural position inside the relevant policy network determines its political leverage.

\section{MNE's political leverage in the home country}

We can now propose a taxonomy of political leverage in the home country according to the institutional characteristics and the MNE's structural position inside the policy network of the concerned domain (Figure 1). 
Figure 1. MNE's political leverage (home country)

TYPE OF POLICY NETWORK

\begin{tabular}{|c|c|c|}
\hline & Open & Closed \\
\hline Strong & a. Negotiated power & b. Dominant position \\
\hline POSITION & & \\
\hline INSIDE THE & & \\
\hline NETWORK & c. Autonomy & $\begin{array}{c}\text { d. Predominance } \\
\text { of other (rival) interests }\end{array}$ \\
\hline
\end{tabular}

Each quadrant defines a certain degree of influence in home politics.

The first cell (a) represents an open institutional structure of the corresponding policy network combined with a strong position of the MNE. The firm controls considerable resources and is well inserted into the network, but its influence has to be negotiated with a variety of other actors having, eventually, rival goals (interest groups, NGOs, etc.). Since there is no exclusivity and dominance, policy options will mainly emerge as acceptable compromises and the outcome concerning the MNE's political leverage is uncertain and unpredictable. Meanwhile, this does not exclude the possibility to promote its interests through stakeholders' alliances (negotiated power). Multi-actor bargaining in the European Union countries concerning deregulation and privatization of public utilities is a typical example of this configuration. 
In the second cell (b), the integration in home country's closed policy networks and the control of relevant non-market assets enable a MNE to pursue effective political influence strategies (dominant position). The MNE's political leverage is significant, especially when national strategic priorities are formulated in the concerned domain and the width of state action is large proportionate to its organizational and institutional capabilities. Linked by a permanent coalition, the government and the MNE have common goals and back one another. As shown by the American authorities supporting Boeing at the expense of Mc Donnell Douglas or Lockeed Martin, companies with a good structural position inside closed policy networks can take advantage of relational strategies and government interventions in the concerned issue-area. The "Big Three" US car makers during the early nineties are another example. In order to reinforce their situation as regards to the Japanese competitors, perceptions of "who is us" (Eden \& Molot, 1993) and strategic trade policies were defined inside an institutional framework characterized by exclusive relationships with the authorities.

In the third case (c), the MNE is not integrated (or occupies a weak position) in the relevant policy network. As a consequence, it does not benefit from political leverage, although it may exert a certain economic power. However, rival interests do not dominate the domain either, given the open character of the network. This means a great autonomy for the MNE's strategic choices but leaves it with limited political support. Numerous Greek manufacturing companies investing in the Balkan countries were confronted to 
this situation (Rizopoulos, 2001).

The fourth configuration (d) corresponds to an issue-area dominated by other (possibly rival) interest groups or by strong state agencies imposing their goals, given the MNE's weak insertion in the corresponding closed policy network. In this case, a MNE not only lack political support but could also bear the brunt of negative political externalities with respect to its activities. This was the case of the Canadian company Talisman involved in the exploitation of oilfields in Sudan. Due to a significant pressure from NGOs and other human rights advocacies on the Canadian government, Talisman was forced to abandon its activities in this country. Defensive strategies mainly based on ownership advantages and market assets would be the only viable option in such cases.

\section{Host country's bargaining power and issue-areas}

A MNE's potential to influence home politics has an impact on its strategic approach towards host countries, and it is plausible to suppose that these relationships are also affected by the bargaining power of the latter.

The conflict-based approach, usually inspired by Vernon's (1971) obsolescing bargaining model, has for some time dominated the literature regarding MNE/host country relationships (Boddewyn, 2005). Stressing on the presumed incompatibility of interests of the two parties, the underlying hypothesis is that the MNE's best strategic option is not the best for the host country (Tang, 1992). 
Currently, we observe a shift towards the recognition of common interests given that both parties earn more when the investment becomes profitable. At the same time, the MNE/host government relationship is considered as multifaceted (Grosse, 2005), while MNEs are perceived as "loosely coupled political systems" or "political arenas" (Sharpe, 2001) rather than homogeneous actors. Subsidiaries develop their own powerful resources (Bluementritt, 2003) and micro-political or inter-cultural conflicts can take place, as shown by a recent research on two Volkswagen Group's subsidiaries in Mexico and in Brazil (Mense-Petermann, 2006). Hillman \& Wan (2005), formalize this idea with the 'institutional duality' concept (subsidiaries search both internal and external legitimacy).

According to the analytical framework developed in this paper, the features of specific issue-areas have an influence on this interactive game and a crucial impact on the host country's actors bargaining power. ${ }^{11}$ Indeed, states with enough economic strength, political will and action capabilities can be moderately interested in specific domains (the French government has not supported Pechiney, a major aluminium company until it was acquired in 2003 by Alcan). Also, the state's action can be weakened because of a high policymaking fragmentation. In China conflicting interests between central and local governments create specific domains for expansion. Foreign companies from the retailing and automobile sectors have overcome strict legal restrictions set

\footnotetext{
${ }^{11}$ Interestingly enough, Vachani (1995) argues that the obsolescing bargaining thesis is verified in India, but an inter-firm differentiation during the re-negotiation process can be observed.
} 
by the central authorities through alliances with local governments interested in employment and taxation benefits (Thun, 2006). Conversely, relatively weak host countries can reveal important bargaining power in some domains as shown by the renegotiation of 61 concession contracts attributed to Suez by the Argentinean government, just after the 2001-2 financial crisis (Wells \& de Royere, 2005).

Proposition 5. Host country's bargaining power has to be apprehended inside each specific issue-area. ${ }^{12}$

\section{MNEs' strategic approach towards host countries}

Political leverage in the home country and host country's bargaining power in the concerned issue-areas will affect the MNE's strategic choices, as it is shown in Figure 2.

Dominant positions in closed home policy networks or the capacity to constitute stakeholders' alliances in open ones involve strong support from the home government. If the host country's actors have an important bargaining power in the corresponding issue-area, the MNE might follow a supranational and macro-political influence approach (area a). In this complex game, goals and aspirations are mutually adapted and the outcome is often unpredictable, as for instance, regarding the internationalization of cultural industries in the Triad countries or the deregulation of telecom markets in

\footnotetext{
${ }^{12}$ Comprehensive micro-political risk assessment (Alon et al., 2006) is compatible with the issue area and policy network approach and can be integrated in the host-country actors' bargaining power.
} 
Europe (Woll, 2007). In some cases, jointly with home governments, MNEs can negotiate the establishment of international standards and rules (protection of intellectual property, removal of entry barriers) at the level of supranational institutions, as WTO. ${ }^{13}$ Such an approach increases the cost borne by the host state if it intends to implement unfriendly policies and usually is supplemented by transnational alliances. In the two-tier multi-party bargaining model developed by Ramamurti (2001), industrialized countries use Tier-1 multilateral bargaining to weaken the hand of host governments in Tier-2 bargaining, while strengthening that of their MNEs. ${ }^{14}$ The strategies pursued by pharmaceutical MNEs regarding the production of generics in the developing countries or by Monsanto promoting genetically modified crops in Latin America demonstrate how supra-national and macro-political influence approaches can improve the control of micro-political risk.

When host country's actors and government have weak bargaining power, MNEs with political leverage at home will be tempted to adopt a conquering approach, imposing unbalanced relationship patterns (area b). This was the attitude of many MNEs in Argentina and in some transition countries during the nineties, securing a monopoly position on the market, repatriating profits without limitations, and acquiring local firms by unfair methods. Also, the home government can exert a direct influence and seriously impair

\footnotetext{
${ }^{13}$ According to Tarzi (1991), the Hickenlooper Amendment and the Gonzales Amendment were the result of corporate lobbying, and both tied American foreign economic interests to the preservation of corporate interests in developing countries.

${ }^{14}$ Interestingly enough, in accordance with the idea of a differentiated impact at the level of various policy-making domains developed here, Ramamurti stresses that the outcome vary across home-host country pairs and industries.
} 
sovereignty of host countries, giving support to the MNE as for the

exploitation of raw materials or privatization programs.

Figure 2. MNE's strategic approach to the host country

Political leverage in home country

\begin{tabular}{|c|c|c|c|c|c|}
\hline \multirow{4}{*}{$\begin{array}{l}\text { Bargaining } \\
\text { power of } \\
\text { local actors }\end{array}$} & & $\begin{array}{l}\text { Dominant } \\
\text { position }\end{array}$ & $\begin{array}{c}\text { Negotiated } \\
\text { power }\end{array}$ & Autonomy & $\begin{array}{l}\text { Predominance } \\
\text { of rival actors }\end{array}$ \\
\hline & Strong & $\begin{array}{l}\text { (a) Supra- } \\
\text { national and } \\
\text { macro- } \\
\text { political }\end{array}$ & IUCII & (c) Adaptive & approach \\
\hline & & (e) Hoybrid & & Hoybrid & \\
\hline & Weak & $\begin{array}{l}\text { Conquering } \\
\text { approach }\end{array}$ & & political & influence \\
\hline
\end{tabular}

A marginal position in the relevant policy networks, the dominance of rival actors, the impossibility to create stable stakeholders alliances, or the lack for state's interest and action capabilities might neutralize the MNEs' political leverage in the home country. In this case, its international strategy is left to rely solely on tangible and intangible market assets. The MNE should manage a more balanced bargaining scheme and, consequently, it will be under pressure of national isomorphism, in particular if its own structure is decentralized (Jansson et al., 1995). When the host country's actors bargaining power is high enough, the MNE will be forced to adopt an adaptive approach 
(area c), searching local legitimacy, taking into account the expectations and interests of local actors and showing receptiveness to public authority requests, especially if its activity belongs to a sovereignty domain of the host country (e.g., the defense industry).

When the host country's actors have a weak bargaining power, the MNE might tend to build-up a certain micro-political influence exploiting its specific ownership advantages and developing exclusive relationships inside some sectors or regions of the host country (area d). The strategy of the US ceramics manufacturer American Standard in Bulgaria constitutes a typical example. The European affiliate of the company has not only created many jobs with high wages compared to the national average in the Sevlievo region; it has also helped modernize the telecommunications system of the region, built a business-class hotel, renovated the local hospital, underwrote university scholarships for local students, reconstructed a sports stadium, rebuilt the local high school and kindergarten, established foreign language classes, and restored an historic church! In this way, it secured an indefectible support from local authorities.

This possibility also depends on the host country's size and administrative-institutional diversity that allows the existence of protected political niches. In China, the French retailer Carrefour entered into direct deals with the local governments of various provinces to get the approval to 
set up its stores. Consequently, Carrefour had emerged as the largest foreign retailer in this country by the early 2000s. ${ }^{15}$

Finally, MNEs pursue hybrid strategies (area e), when the balance of power is not well established. The penetration strategy of Japanese car makers in US and Europe during the nineties is an example of an approach combining attempts of influence at a supra-national (WTO) level with an adaptive ("good citizen") approach. Also, some European companies without political leverage at home have pursued hybrid strategies in order to expand in the Balkan countries combining adaptive and micro-political influence approaches. ${ }^{16}$

\section{Conclusions and discussion}

The institutional framework and the relationship patterns with state/government actors constitute a crucial factor as regards the MNEs' political leverage and strategic choices.

MNEs intervene in the political decision-making process through relevant policy networks characterized by various types of interdependencies. The institutional features of these networks (open or closed) and the MNE's structural position inside them differentiate the latter's political influence in each issue-area. Insertion in closed policy networks and significant controlled resources mean greater MNE's leverage for political action.

\footnotetext{
${ }^{15}$ See "Carrefour's strategies in China", ICMR case study, BSTR 246, 2007.

${ }^{16}$ As, for instance, the Greek firm St George's Mills, in Romania (see "Commercial Capital SA", Harvard Business School case study 9-901-005, 2001).
} 
The different types of MNEs' institutional embeddedness inside home policy networks imply a variety of strategic choices, taking also into account the local actors' bargaining power in each specific issue-area. Globally, the absence of political support would be favorable to adaptive approaches, while conquering strategies might dawn in the case of strong political leverage at home. Conversely, a strong position of host countries' concerned actors would moderate the MNEs' intentions, imposing search for indirect supra-national influence or local legitimacy. Hybrid strategies are pursued in the case of balanced bargaining power.

Departing from the analytical framework proposed here, future research can be orientated towards both theoretical and empirical directions.

Regarding the conceptual framework, we consider the two figures developed in the paper as a useful initial insight of the MNE's political leverage and its impact on strategic choices. For the purpose of our modelling we have restricted the figures to one issue-area. However, political influence games are more complex and sophisticated. Indeed, home and host countries have dealings on various issues over time and MNEs operate in numerous markets. Furthermore, the interaction patterns and systems of interest intermediation in which firms are embedded are not absolutely constraining. MNEs have the possibility to select different combinatory options and the way they move into a host country cannot be given by a mathematical relationship. As a consequence, some trade-offs between a more profound analysis of real 
life processes and the simplified forms of the matrixes presented here seem useful.

It would be interesting to study the interaction patterns when one MNE intervenes in different but related policy networks (issue-areas), the links between policy networks in the home and host countries, the articulation of national, subnational and supranational levels, and the impact of decentralized MNEs' structure related to the question of institutional duality.

Case studies of specific issue-areas would reveal the structural features of the corresponding policy networks and the business/government interaction patterns. Factors such as interdependencies arising from the division of available resources, types and density of links, formal and informal rules of the game can be integrated in formal models issued from the graphs theory enabling to measure the MNE's influence at home and appreciate its strategic approach towards specific host countries. Also, a comparative approach could involve a formal survey of a large number of MNEs or focus on how two companies, one powerful and the other weak at home, lobby in a single sector of the host country.

\section{References}

Alon, Ilan, Gurumoorthy, Rajesh, Mitchell, Matthew C., \& Steen, Teresa (2006). Managing micropolitical risk: A cross sector examination, Thunderbird International Business Review, 48 (5): 623-642.

Anastassopoulos, Jean-Pierre, Blanc, Georges, Nioche, Jean-Pierre, \& Ramanantsoa, Bernard (1985). Contingence et liberté - Pour une nouvelle politique d'entreprise, PUF, Paris. 
Baron, David P (1995). Business and its environment. Prentice Hall.

Baysinger, Barry (1984). Domain maintenance as an objective of business political activity: An expanded typology. Academy of Management Review, 9 (2): 248-258.

Blumentritt, Timothy (2003). Foreign subsidiaries' government affairs activities. The influence of managers and resources. Business \& Society, 42 (2): 202-233.

Boddewyn, Jean (1988). Political aspects of MNE theory. Journal of International Business Studies, 19 (3): 341-363.

Boddewyn, Jean (2005). Early US business-school literature (1960-1975) on international business-government relations: its twenty-first-century relevance. Pp. 25-47 in R. Grosse (ed) International business government relations in the $21^{\text {st }}$ century. Cambridge University Press.

Boddewyn, Jean, \& Brewer, Thomas (1994). International-business political behavior: New theoretical directions. Academy of Management Review, 19 (1): 119-143.

Bonardi, Jean-Philippe, \& Keim, Gerald (2005). Corporate political strategies for widely salient issues. Academy of Management Review, 30 (3): 555-576.

Bourdier, Pierre (1985). The forms of capital. Pp. 241-258 in J. Richardson (ed) Handbook of theory and research for the sociology of education, Greenwood, New York.

Brewer, Thomas (1992). An issue-area approach to the analysis of MNE-Government Relations. Journal of International Business Studies, 23 (2): 295-309.

Brewer, Thomas (2005). Global warming and climate change: new issues for business strategy, government policy, and research on business-government relations. Pp. 147-170 in R...Grosse (ed) International business government relations in the $21^{\text {st }}$ century. Cambridge University Press.

Burt, Ronald S. (1992). Structural holes: The social structure of competition. Harvard University Press, Cambridge.

Coleman, James C. (1988). Social capital in the creation of human capital. American Journal of Sociology, vol. 94 (supplement): s95-s120.

Eden, Lorraine, Lenway, Stefanie \& Schuler, Douglas (2005). From the obsolescing bargain to the political bargaining model. Pp. 251-271 in R. Grosse (ed), International Business-Government relations in the 21th century, Cambridge University Press.

Eden, Lorraine, \& Molot, Maureen (1993). Insiders and outsiders: Defining "Who is us?" in the North American auto industry. Transnational Corporations, 2 (3): 3164.

Epstein, Edwin M. (1969). The Corporation in American Politics. Englewood Cliffs, NJ: Prentice Hall.

Freeman, Lieper J. \& Parris Stevens, J. (1987). A theoretical and conceptual reexamination of subsystem politics. Public Policy and Administration, 2 (1): 9-24. 
Getz, Kathleen.A. (1997). Research in Corporate Political Action. Business \& Society, 36 (1): 32-72.

Granovetter, Mark (1973). The strength of weak ties. American Journal of Sociology, 78 (6): 1360-1380.

Granovetter, Mark (1985). Economic action and social structure: The problem of embeddedness. American Journal of Sociology, 91 (3): 481-510.

Grosse, Robert (2005). The bargaining view of government-business relations. Pp. 273-289 in R. Grosse (ed), International Business-Government relations in the 21th century. Cambridge University Press.

Hillman, Amy (2003). Determinants of political strategies in U.S. multinationals. Business \& Society, 42 (4): 455-484.

Hillman, Amy, \& Hitt, Michael (1999). Corporate political strategy formulation: a model of approach, participation level and strategy decisions. Academy of Management Review, 24 (4), October: 825-842.

Hillman, Amy, \& Keim, Gerry (1995). International variation in the BusinessGovernment interface: Institutional and organizational considerations. Academy of Management Review, 20 (1): 193-214.

Hillman, Amy, Keim, Gerry, \& Schuler, Douglas (2004). Corporate political activity: A review and research agenda. Journal of Management, 30 (6): 837-857.

Hillman, Amy, \& Wan, William (2005). The determinants of MNE subsidiaries' political strategies: evidence of institutional duality. Journal of International Business Studies, 36: 322-340.

Jansson, Hans, Saqib, M. \& Deo Sharma, D. (1995). The state and transnational corporations. Aldershot, Edward Elgar.

Katzenstein, P. ed. (1978). Between power and plenty: Foreign economic policies in advanced industrial states. Madison, Wisconsin, University of Wisconsin Press.

Keim, Gerry .D. \& Zeithaml, Carl. P. (1986). Corporate political strategy and legislative decision making: A review and contingency approach. Academy of Management Review, 11 (4): 828-843.

Keillor, Bruce \& Hult, G. Tomas M. (2004). Predictors of firm-level political behavior in the global business environment: an investigation of specific activities employed by US firms. International Business Review, 13 (3): 309-329.

Klijn E.-H. \& Teisman G.R. (1997). Strategies and games in networks. Pp. 98-118 in W. Kickert et al. (eds), Managing complex networks. Strategies for the public sector. Sage Publications, London-Thousand Oaks.

Laumann, E., \& Knoke, D. (1987). The organizational state: Social choice in national policy domains. University of Wisconsin Press, Wisconsin.

Lenway, Stephanie A., \& Rehbein, Kathleen (1991). Leaders, followers, and free riders: An empirical test in corporate political involvement. Academy of Management Journal, 34: 893-905. 
Levine, Sol, \& White, Paul (1961). Exchange as a conceptual framework for the study of interoganizational relationships. Administrative Science Quarterly, 5: 583601 .

Levy, David, \& Prakash, Aseem (2003). Bargains old and new: Multinational corporations in global governance. Business and Politics, 5 (2): 131-150.

Mense-Petermann, Ursula (2006). Micro-political or intercultural conflicts? - An integrating approach, Journal of International Management, 12: 302-317.

Murtha, Tom, \& Lenway, Stephanie A. (1994). Country capabilities and the strategic state: How national political institutions affect multinational corporations' strategies. Strategic Management Journal, 15, Summer: 113-129.

Ouimet, Matieu, \& Lemieux, Vincent (2000). Les réseaux de politique publique : un bilan critique et une voie de formalisation. Cahiers de Recherche, Centre d'Analyse des Politiques Publiques, Université Laval.

Pfeffer, Jeffrey, \& Salancik, Gerald (1978). The external control of organizations: A resource dependence perspective. Harper and Row, New York, 1978.

Ramamurti, Ravi (2001). The obsolescing "Bargaining Model”? MNC-Host developing country relations revisited. Journal of International Business Studies, 32 (1): 23-39.

Rhodes, Rod (1981). Control and power in central-local relations. Gower: Aldershot.

Rhodes, Rod (1986). The national world of local government. George Allen \& Unwin: London.

Rhodes, Rod, \& Marsh David (1990). New direction in the study of policy networks. European Journal of Political Research, 21 (1): 181-205.

Ripley, Randall, \& Franklin, Grace (1987). Congress, the bureaucracy and public policy. Dorsey, Homewood (first published 1976).

Rizopoulos, Yorgos (2001). Foreign direct investment and western firms' internationalization strategies in the Balkan countries. Pp. 75-111 in G. Petrakos \& $\mathrm{S}$. Totev (eds), The development of the Balkan region, Ashgate, Aldershot.

Rodriguez, Peter, Siegel, Donald, Hillman, Amy \& Eden, Lorraine (2006). Three lenses on the multinational enterprise: politics, corruption, and corporate social responsibility. Journal of International Business Studies, 37: 733-746.

Ruggie, John Gerard (2001). global_governance.net: The Global Compact as learning network. Global Governance, 7: 371-378.

Schaap, L. \& van Twist, M.J.W. (1997). The dynamics of closedness in networks. Pp. 62-78 in W. Kickert et al. (eds), Managing complex networks. Strategies for the public sector, Sage Publications, London-Thousand Oaks.

Sharpe, D.R. (2001). Globalization and change: organizational continuity and change within a Japanese multinational in the UK. Pp. 196-221 in Morgan et al. (eds), The multinational firm, Organizing across institutional and national divides, Oxford University Press, Oxford. 
Tang, Ming-Je (1992). Regulating the entry of multinational enterprises: models and practices. The International Trade Journal, 7(1): 131-150.

Tarzi, Shah (1991). Third world governments and multinational corporations: Dynamics of host's bargaining power. International Relations, X (3): 237-249.

Thun, Eric (2006). Changing lanes in China: Foreign direct investment, local governments, and auto sector development. Cambridge University Press.

Vachani, Sushil (1995). Enhancing the obsolescing bargain theory: a longitudinal study of foreign ownership of US and European multinationals. Journal of International Business Studies, 26 (1): 159-180.

Vernon, Raymond (1971). Sovereignty at bay: The multinational spread of US enterprises. Basic Books.

Vogel, David J. (1996). The study of business and politics. California Management Review, 38 (3): 146-162.

Wells, Louis \& De Royere Alexandra (2005). Aquas Argentinas: Settling a dispute, Harvard Business School Cases, 30 March 2005.

Wilks, Stephen \& Wright, Maurice, eds (1987). Comparative government-industry relations, Western Europe, the United States and Japan. Oxford: Clarenton Press.

Windsor, Duane (2007). Toward a global theory of cross-border and multilevel corporate political activity. Business \& Society, 46 (2): 253-278.

Woll, Cornelia (2007). From national champions to global players? Lobbying by network operators during the WTO's basic telecommunication negotiations. Business \& Society, 46 (2): 229-252.

Yoffie, David B. (1988). How an industry builds political advantage. Harvard Business Review, May-June. 